\title{
BAKTERI Lactobacillus spp DAN PERANANNYA BAGI KEHIDUPAN
}

\author{
Milfa Aini ${ }^{1}$, Sri Rahayuni ${ }^{1}$, Vivi Mardina ${ }^{1 *}$, Quranayati $^{2}$, Nur Asiah ${ }^{3}$ \\ ${ }^{1}$ Program Studi Biologi, Fakultas Teknik, Universitas Samudra, Jl. Prof. Syarief Thayeb, \\ Meurandeh, Langsa, Aceh, Indonesia. 24416 \\ ${ }^{2}$ Program Studi Pascasarjana, Doktor Matematika dan Aplikasi Sains, Universitas Syiah Kuala \\ ${ }^{3}$ Departemen Keperawatan Maternitas Anak, Fakultas Keperawatan, Universitas Sumatera \\ Utara \\ *E-mail koresponden: vmardina@unsam.ac.id
}

\begin{abstract}
ABSTRAK
Bakteri Asam Laktat (BAL) adalah kelompok bakteri dari genus Lactobacillus yang memiliki 106 spesies, namun hanya 56 spesies berpotensi sebagai probiotik. Bakteri Asam Laktat dapat dimanfaatkan sebagai probiotik. Lactobacillus bertindak sebagai agen probiotik dan flora normal sehingga dapat berperan untuk membatasi pertumbuhan bakteri patogen. Lactobacillus juga berfungsi untuk menjaga sistem imun atau kekebalan tubuh. Hal ini disebabkan oleh kemampuan Lactobacillus dalam menghambat pertumbuhan bakteri patogen, merangsang pembentukan antibodi, selain itu genus Lactobacillus banyak digunakan untuk fermentasi dan pengawet makanan.. Penelitian ini menggunakan metode deskriptif restrospektif. Sampel penelitian berupa kajian literaturi dari jurnal dan penelitian yang telah diterbitkan. Tujuan penelitian ini adalah mereview berbagai jenis bakteri Lactobacillus spp dan perannya dalam kehidupan.
\end{abstract}

Kata kunci: Lactobacillus, Asam laktat, Probiotik, Fermentasi

\begin{abstract}
Lactic Acid Bacteria (LAB) is a group of bacteria from the genus Lactobacillus which has 106 species, but only 56 species have the potential as probiotics. Lactic acid bacteria can be used as probiotics. Lactobacillus acts as a probiotic agent and normal flora so that it can play a role in limiting the growth of pathogenic bacteria. Lactobacillus also functions to maintain the immune system. This is due to the ability of Lactobacillus in inhibiting the growth of pathogenic bacteria, stimulating the formation of antibodies, besides that the genus Lactobacillus is widely used for fermentation and food preservatives. This study used a retrospective descriptive method. The research sample is a literature review from published journals and research. The purpose of this study was to review various types of Lactobacillus spp. bacteria and their roles in life.
\end{abstract}

Keywords: Lactobacillus, lactic acid, probiotic, fermentation 
Jurnal Jeumpa, 8 (2) Juli-Desembaer 2021

\section{PENDAHULUAN}

Bakteri adalah organisme berukuran mikro dan tidak memiliki membran inti sel (nukleus) sehingga diperlukan alat bantu mikroskop untuk mengidentifikasi jenis dan bentuknya. Secara umum, keberadaan bakteri masih dianggap patogen penyebab berbagai penyakit infeksi pada manusia, tumbuhan, maupun hewan (Fadila et al., 2019). BAL merupakan organisme menguntungkan karena dapat memfermentasi molekul karbohidrat untuk menghasilkan asam laktat. Karakteristik BAL bereaksi pada pewarnaan gram dan akan negatif bereaksi terhadap katalase (Aulya et al., 2020). Beberapa BAL bersifat antimikroba. Spesies lain BAL mampu memproduksi enzim BSH (Bile Salt Hidrolase) yang berfungsi mendegredasi lemak jenuh menjadi lemak tak jenuh, sehingga produk ternak yang dihasilkan akan bebas kolesterol. Salah satu genus yang dikelompokan BAL adalah Lactobacillus.

Lactobacillus umumnya flora normal, berperan sebagai agen probiotik yang berfungsi menghambat pertumbuhan bakteri pathogen dan juga berfungsi untuk imunitas (kekebalan tubuh). Hal ini sesuai penjelasan Rusli, et. al,. (2018) yaitu (1) Lactobacillus membantu pembentukan antibodi yang hubungannya dengan IgA sehingga mencegah bakteri patogen tumbuh, (2) kemudian dapat memulihkan kondisi keseimbangan usus setelah diberikan antibiotik dan (3) kemoterapi, (4) dapat mencegah infeksi saluran kemih dan (5) pembentukan gas akibat proses enzimatis (pembusukan). Beberapa jenis BAL terdapat disaluran pencernaan, di antaranya Lactobacillus crispatu, Lactobacillus ruminis, Lactobacillus johnsonii, Bifidobacterium bifidum, Lactobacillus, Bifidobacterium adolescentris salivarius, Bifidobacterium longum, Lactobacillus vitulinus, Bifidobacterium infantis, Lactobacillus reuteri, L.acidophilus, dan L. gasseri, dan (Surono, 2004).

Lactobacillus dikenal bakteri yang bermanfaat pada bidang kesehatan dan makanan sehingga banyak diaplikasikan sebagai pengawet minuman maupun makanan. Bakteri probiotik dapat membantu produksi vitamin, berperan dalam penyerapan makanan, menjaga kesehatan usus, mencegah pertumbuhan bakteri patogen, dan membantu metabolisme lipid/kolesterol, menghambat proses penuaan dan berperan mencegah karsinogenesis. Hasil penelitian Heprer et al., (1979) menemukan suplemen yoghurt yang diberikan rutin selama 7 hari mampu menurunkan kadar serum kolesterol 
manusia. Yoghurt dan susu menginduksi hypercholesterolemia yang berakibat menurunkan kadar kolesterol. Lactobacillus sebagai produk probiotik mempunyai keunggulan yang besar dibandingkan bakteri asam laktat yang lain. Tetapi BAL yang terdapat dalam saluran pencernaan memiliki kelemahan yaitu mudah mengalami perubahan jumlah (Muriana \& Klaenhammer, 1987; Davis \& Gasson. 1981). Salah satu manfaat lain dari Lactobacillus dalam bentuk minuman probiotik yaitu untuk kesehatan. Produk makanan fermentasi, susu, buah-buahan, daging, dan olahan ikan banyak mengandung bakteri Lactobacillus (Napitupulu et al., 1997).

Ada banyak jenis Lactobacillus seperti L. bulgaricus dan L. plantarum yang diaplikasikan pada pembuatan minuman probiotik menggunakan metode fermentasi seperti minuman probiotik dari sari buah pepaya atau sayuran dan jenis buahan lainnya (Primurdia dan Kusnadi, 2014). Lactobacillus sebagai bakteri BAL mampu memproduksi asam laktat dan senyawa bakteriosin yang berfungsi mencegah atau membunuh bakteri patogen dalam usus. Contohnya adalah L. casei. Jannah et al. (2014) menyatakan Lactobacillus acidophilus mampu menurunkan keasaman proses fermentasi dengan cepat (Jannah et al. 2014). Beberapa BAL bersifat homofermentatif seperti Streptococcus thermophiles, Lactobacillus acidophilus dan Lactobacillus bulgaricus. Homofermentatif yaitu mampu memproduksi asam laktat sekaligus asam asetat dari metabolisme karbohidrat melalui jalur Embden Meyarhoff (heksosa difosfat, HDP). Adapun heterofermentatif, asal laktat akan dihasilkan melalui jalur Heksosa Monofosfat (HMP) atau pentosa fosfat atau fosfoketolase. Asam laktat ini kemudian dapat dikonversi ke asam asetat, asam propionat dan butirat melalui jalur asetil-KoA (Novia, 2012).

Beberapa jenis BAL menghasilkan bakteriosin seperti peptide yaitu jenis protein, yang bersifat bakterisidal dan bakteriostatik. Bakteriosin biasa dihasilkan oleh bakteri Gram positif. Sifat bakterisidal maupun bakteriostatik mencegah pertumbuhan bakteri sejenis lainnya dan berfungsi sebagai alat pelekat spesifik bagi patogen sehingga membedakan dengan senyawa antimikroba lainnya. Senyawa anti mikroba ini di hasilkan dari jenis Lactobacillus yang bersifat antibakteri, (Surono, 2004).

Proses fermentasi bantuan dari bakteri asam laktat atau BAL dapat menghasilkan produk yang bermanfaat untuk mencegah 
pertumbuhan mikroba patogen yang merugikan bagi tubuh selain itu juga dapat memecah laktosa susu menjadi senyawa yang lebih sederhana, dapat meningkatkan nilai gizi yang lebih tinggi dibandingkan dengan bahan asalnya sehingga dapat dengan mudah dicerna oleh tubuh, penggunaan bakteri asam laktat juga dapat menambah beberapa vitamin seperti vitamin B12, provitamin A dan riboflavin (Adriani et. al. 2008).

\section{METODE PENELITIAN}

\section{Konvensional literature review} merupakan metode yang diadopsi pada penulisan artikel ini. Literatur dicari menggunakan Proquest google scholar, EBSCO, dan ScienceDirect, sebagaimana yang disarankan oleh Makhfirah et al. (2020). Situs NCBI dan google scholar (https://scholar.google.co.id/) juga digunakan dengan kata kunci yaitu "(a) identifikasi, (b) Lactobacillus Spp dan (c) peran Lactobacillus Spp”. Penelitian dilakukan pada November 2020 .

\section{HASIL DAN PEMBAHASAN}

Data deskripsi bakteri dan peran bakteri Lactobacillus Spp ditampilkan pada tabel 1 dibawah.
Tabel. 1 Jenis dan peran Lactobacillus spp

\begin{tabular}{|c|c|c|}
\hline No & Nama Bakteri & Manfaat \\
\hline 1 & $\begin{array}{l}\text { Lactobacillus } \\
\text { acidophilus }\end{array}$ & $\begin{array}{llr}\text { Antidiare dan } & \text { dapat } \\
\text { meningkatkan sistem } & \text { imun. } \\
\text { Namun, bakteri ini } & \text { dapat } \\
\text { menyebabkan karies gigi. } & \text { (Rusli } \\
\text { et.al., 2018) } & & \end{array}$ \\
\hline 2 & $\begin{array}{l}\text { Lactobacillus } \\
\text { rhamnosus }\end{array}$ & $\begin{array}{l}\text { Dapat mencegah diare dan } \\
\text { menurunkan resiko } \text { infeksi } \\
\text { saluran pencernaan.( Nuraida } \\
\text { et.al., 2012) }\end{array}$ \\
\hline 3 & $\begin{array}{l}\text { Lactobacillus } \\
\text { casei }\end{array}$ & $\begin{array}{l}\text { Memecah limbah di dalam tubuh } \\
\text { sehingga dapat membantu } \\
\text { penyerapan vitamin dan mineral } \\
\text { (Yanuar } \text { et. al., 2015). }\end{array}$ \\
\hline 4 & $\begin{array}{l}\text { Lactobacillus } \\
\text { reuteri }\end{array}$ & 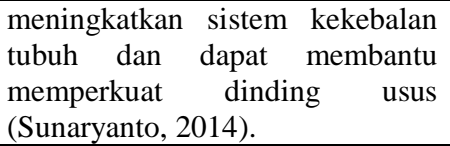 \\
\hline 5 & $\begin{array}{l}\text { Lactobacillus } \\
\text { plantarum }\end{array}$ & 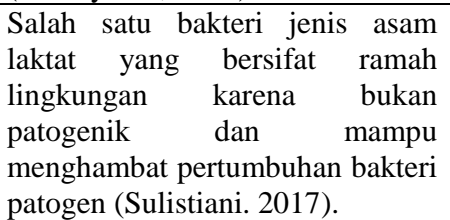 \\
\hline 6 & $\begin{array}{l}\text { Lactobacillus } \\
\text { gasseri }\end{array}$ & $\begin{array}{l}\text { Memecah limbah tubuh sehingga } \\
\text { membantu pencernaan bakteri dan } \\
\text { mineral. Bakteri ini biasa } \\
\text { ditemukan pada sistem } \\
\text { pencernaan, saluran kemih dan } \\
\text { kelamin (Otieno, 2011). }\end{array}$ \\
\hline 7 & $\begin{array}{l}\text { Lactobacillus } \\
\text { delbrueckii } \\
\text { subsp. } \\
\text { Bulgaricus }\end{array}$ & $\begin{array}{l}\text { Berperan dalam pembentukan } \\
\text { yoghurt. } \\
\text { delbrueckii subsp. Bulgacillus } \\
\text { digunakan sebagai starter culture } \\
\text { untuk fermentasi produk susu } \\
\text { (Teguh, 2008). } \\
\end{array}$ \\
\hline 8 & $\begin{array}{l}\text { Lactobacillus } \\
\text { paracasei }\end{array}$ & $\begin{array}{l}\text { Meningkatkan daya tahan tubuh, } \\
\text { anti peradangan dan menjaga } \\
\text { pencernaan lebih baik dan } \\
\text { mengurangi keaktifan bakteri } \\
\text { berbahaya (sumber penyakit) } \\
\text { (Suryani et.al., 2017) }\end{array}$ \\
\hline 9 & $\begin{array}{l}\text { Lactobacillus } \\
\text { fermentum }\end{array}$ & $\begin{array}{lrr}\begin{array}{l}\text { Memiliki } \\
\text { terhadap }\end{array} & \begin{array}{r}\text { ketahanan } \\
\text { antibiotik }\end{array} \\
\text { kemoterapi } & \text { dami } \\
\text { tertentu } & \text { (Fahmida, } \\
\text { 2010). } & & \\
\end{array}$ \\
\hline 10 & $\begin{array}{l}\text { Lactobacillus } \\
\text { helveticus }\end{array}$ & $\begin{array}{l}\text { Bakteri penghasil asam laktat } \\
\text { berbentuk batang. Bakteri baik } \\
\text { yang hidup didalam sistem } \\
\text { pencernaan manusia (Lu et.al., } \\
\text { 2003). }\end{array}$ \\
\hline 11 & $\begin{array}{l}\text { Lactobacillus } \\
\text { crispatus }\end{array}$ & $\begin{array}{l}\text { Bakteri spesies biota mikro } \\
\text { menguntungkan } \\
\text { yang } \\
\text { menghasilkan hidrogen peroksida } \\
\text { yang terletak di vagina, melalui } \\
\text { keputihan dan saluran pencernaan } \\
\text { vertebrata (Claesson et. al., } \\
\text { 2007). }\end{array}$ \\
\hline
\end{tabular}




\begin{tabular}{|c|c|c|}
\hline 12 & $\begin{array}{l}\text { Lactobacillus } \\
\text { Salivarius }\end{array}$ & $\begin{array}{l}\text { merupakan spesies bakteri } \\
\text { probiotik yang telah ditemukan } \\
\text { pada saluran pencernaan dan } \\
\text { mengerahkan berbagai sifat } \\
\text { terapteutik termasuk penekanan } \\
\text { bakteri patogen (Usmiati, 2009). }\end{array}$ \\
\hline 13 & $\begin{array}{l}\text { Lactobacillus } \\
\text { brevis }\end{array}$ & $\begin{array}{l}\text { berperan dalam proses pembuatan } \\
\text { asinan buah buahan dan sayuran } \\
\text { (Setiarto et. al., 2018). }\end{array}$ \\
\hline 14 & $\begin{array}{l}\text { Lactobacillus } \\
\text { jhonsonii }\end{array}$ & $\begin{array}{l}\text { mempunyai peran penting pada } \\
\text { sistem pencernaan bayi. } L \\
\text { jhonsonii (Gibson et. al., 2000) }\end{array}$ \\
\hline 15 & $\begin{array}{l}\text { Lactobacillus } \\
\text { sakei }\end{array}$ & $\begin{array}{l}\text { Bakteri ini mampu memproduksi } \\
\text { berbagi macam senyawa anti } \\
\text { mikroba seperti asam organik, } \\
\text { bakteriosin sehingga dapat } \\
\text { menghambat pertumbuhan bakteri } \\
\text { patogen (Badel, 2011). }\end{array}$ \\
\hline 16 & $\begin{array}{l}\text { Lactobacillus } \\
\text { iners }\end{array}$ & $\begin{array}{l}\text { berbentuk batang gram-positif } \\
\text { yang menghuni normal saluran } \\
\text { reproduksi bawah pada wanita } \\
\text { sehat (Manin, 2006). }\end{array}$ \\
\hline 17 & $\begin{array}{l}\text { Lactobacillus } \\
\text { sanfranciscen } \\
\text { sis }\end{array}$ & $\begin{array}{l}\text { Bakteri asam laktat yang melalui } \\
\text { produksi. Membantu memberikan } \\
\text { rasa khas pada roti.( Wardinal et. } \\
\text { al.,2019) }\end{array}$ \\
\hline 18 & $\begin{array}{l}\text { Lactobacillus } \\
\text { buchneri }\end{array}$ & $\begin{array}{l}\text { menghasilkan asam laktat dan } \\
\text { asetat selama fermentasi (Farinde } \\
\text { et. al., 2010). }\end{array}$ \\
\hline 19 & $\begin{array}{l}\text { Lactobacillus } \\
\text { hilgardii }\end{array}$ & $\begin{array}{l}\text { Perannya dalam fermentasi } \\
\text { anggur. Dan dapat membusukan } \\
\text { materi tanaman (Krishna et.al., } \\
\text { 2008). }\end{array}$ \\
\hline 20 & $\begin{array}{l}\text { Lactobacillus } \\
\text { kimchii }\end{array}$ & $\begin{array}{l}\text { pembuatan karakter khusus pada } \\
\text { sayuran dan buah buahan yang } \\
\text { terfermentasi, misalnya makanan } \\
\text { kimchi yang terfermentasi } \\
\text { (Khusaini, 2014) }\end{array}$ \\
\hline 21 & $\begin{array}{l}\text { Lactobacillus } \\
\text { fructivorans }\end{array}$ & $\begin{array}{l}\text { Bakteri ini berperan sebagai } \\
\text { proses metabolisme yang } \\
\text { menghasilkan asam laktat dan } \\
\text { fermentasi (Usmiati, 2009). }\end{array}$ \\
\hline 22 & $\begin{array}{l}\text { Lactobacillus } \\
\text { kefiri }\end{array}$ & 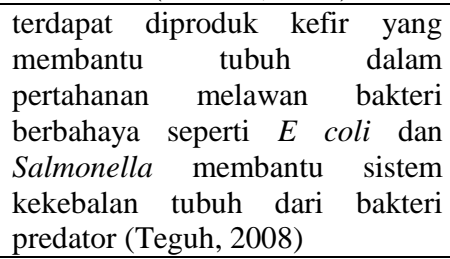 \\
\hline 23 & $\begin{array}{l}\text { Lactobacillus } \\
\text { gallinarum }\end{array}$ & $\begin{array}{l}\text { Berpotensi sebagai bakteri } \\
\text { probiotik dengan merangsang } \\
\text { respon kekebalan tubuh (Adams, } \\
\text { 2008). }\end{array}$ \\
\hline 24 & $\begin{array}{l}\text { Lactobacillus } \\
\text { parakefiri }\end{array}$ & 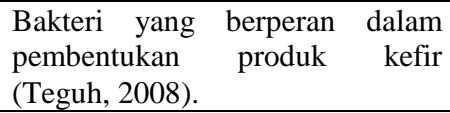 \\
\hline 25 & $\begin{array}{l}\text { Lactobacillus } \\
\text { fabifermentan } \\
s\end{array}$ & $\begin{array}{lrr}\text { Bakteri yang } & \text { memilki } \\
\text { kemampuan untuk } & \text { materi } \\
\text { tanaman dan } & \text { membusukkan } \\
\text { memproduksi } & \text { asam } & \text { laktat } \\
\text { (Wikandari et.al., } & \text { 2012). } & \\
\end{array}$ \\
\hline
\end{tabular}

Lactobacillus adalah genus BAL yang aman, berhabitat pada saluran gastrointestinal hewan dan manusia dengan jumlah mencapai 19 × $10^{7} \mathrm{CFU} / \mathrm{mL}$ (Manin et al., 2006). Peranan Lactobacillus terutama pada proses fermentasi pangan yang aplikasinya untuk kesehatan. Hasil fermentasi utama yang melibatkan proses fermentasi bakteri asam laktat seperti yoghurt, keju, susu fermentasi, bekasam, tempoyak, sourkraut, dan sawi asin.

BAL genus Lactobacillus berkarakteristik yaitu: Gram positif, selnya rods (coccobacilli) negatif pada pengujian acid-tolerant katalase, tidak berspora, kandungan $\mathrm{G}+\mathrm{C}$ rendah, anaerobic, dan fastidious (asam laktat yang bersubstrat glukosa) (Claesson, et al., 2007). Holt et al., (1994) menambahkan ciri morfologi lain yaitu: koloni berwarna putih susu atau cream, bulat, sel nya batang dan tetap dengan ukuran $0,5-1,2 \times 1,0-10,0 \mu \mathrm{m}$, bertahan hidup pada suhu optimum yaitu suhu 30-37 ${ }^{\circ} \mathrm{C}$, Gram positif $(+)$, nonmotil, katalase negatif, dengan kadar pada $\mathrm{NaCl} 3$ 7\%. Beberapa BAL bersifat mikroaerofilik, atau fakultatif anaerob. Bentuk koloni entire, cembung, dan buram (opaque).

Lactobacillus merupakan jenis bakteri dengan genus terbesar dalam kelompok BAL (memiliki hampir 106 spesies) dengan 
sekitar 60 spesies berpotensi probiotik (Otieno, 2011). Jenis Lactobacillus dapat dibedakan menjadi kelompok yaitu bersifat homofermentatif dan heterofermentatif. Dilihat dari kemampuan fermentasinya, genus Lactobacillus diklasifikasikan menjadi (1) obligat homofermentatif ( $L$. acidophilus, L.delbrueckii subsp. delbrueckii, Lactobacillus helveticus, $L$. salivarius), (2) fakultatif heterofermentatif (L. casei, L. curvatus, L. plantarum, dan L.sakei) dan (3) obligat heterofermentatif (L.brevis, L. buchneri, L. fermentum, L. reuteri) (Adams, et. al. 2008; Hammes \&Vogel, 1995).

Genus Lactobacillus umumnya diaplikasikan pada proses fermentasi dan pengawet makanan. Hal ini disebabkan karena genus ini mampu memproduksi senyawa metabolit yaitu, alkohol, hidrogen peroksida dan asam organik, serta zat lainnya (bakteriosin). (Daeschel, 1989). Penelitian Usmiati et al. (2009) berhasil mengisolasi Lactobacillus $s p$ dari susu sapi segar yang aktif tumbuh pada suhu $27^{\circ} \mathrm{C}$ dan $\quad 4^{\circ} \mathrm{C}$. Isolat Lactobacillus $s p$ memproduksi bakteriosin yang menghambat pertumbuhan Salmonella thypimurium dan Escherichia coli.

Beberapa bakteri yang memiliki manfaat baik dari bakteri genus
Lactobacillus adalah bakteri Lactobacillus acidophilus. L. acidophilus bersifat Gram positif, basil, non- motil dan non spora, mampu bertahan pada $\mathrm{pH}$ asam (dibawah $\mathrm{pH}$ 4). Pada sistem digestoria berfungsi merangsang kekebalan tubuh yang ditandai dengan peningkatan nilai titer antibodi, indek fagositik, serta jumlah leukosit, limfosit, neutrofil (Hardiningsih et al., 2004 dan Rusli, 2018). Namun, Lacidophilus dapat juga bersifat negatif yaitu penyebab karies, karena asidogenik dan asidurik (hidup pada suasana asam) sehingga struktur gigi menjadi rusak akibat fermentasi bakteri (Slots dan taubman, 1992).

Lactobacillus rhamnosus digolongkan sama dengan Lactobacillus casei. Namun, berbagai hasil penelitian menyimpulkan dan mengelompokan bakteri Lactobacillus rhamnosus sebagai spesies tersendiri. L.rhamnosus yang dimanfaatkan sebagai sumber probiotik telah diaplikaiskan pada produk minuman seperti yoghurt, susu bubuk. Manfaat lain dari bakteri Lactobacillus rhamnosus yaitu ampuh mengobati penyakit diare yang disebabkan karena infeksi enterophatogenic $E$ coli (EPEC). Hal ini di karena kan adanya asam laktat yang di produksi Lactobacillus rhamnosus yang dapat membunuh bakteri merugikan di saluran pencernaan, selain itu 
juga dapat menurunkan resiko infeksi saluran pencernaan dengan cara meningkatkan jumlah sel $\mathrm{T}$, yaitu sekumpulan sel darah putih yang berperan dalam sistem kekebalan (Nur Aida, et al., 2012).

Lactobacillus plantarum merupakan jenis BAL yang ramah lingkungan karena tidak bersifat patogenik dan mampu menghambat pertumbuhan bakteri patogen. Pada aplikasi pengawet makanan, syarat yang harus dipenuhi yaitu bakteri bersifat antagonis dengan spektrum luas terhadap bakteri dan jamur patogen lain dalam bahan pangan. Dan bakteri Lactobacillus plantarum ini memilki sifat antagonis (Ghanbari et al., 2013 dan Sulistiani, 2017). Bakteri jenis Lactobacillus delbrueckii subsp. berkarakteristik basil gemuk, hidup berkoloni, warna ungu dan gram positif (lapisan peptidoglikan tebal pada dinding selnya dan mampu menyerap warna violet saat pewarnaan) (Levinna, et al., 2018). L. delbrueckii mampu mendegradasi gula menjadi asam laktat atau komponen lainnnya (Badel et al., 2011).

\section{Lactobacillus casei bersifat} biopresevatif dengan daya hambat terbesar dibandingkan dengan bakteri asam laktat lainnya. Ia mampu memproduksi plantaricin (Fardiaz, 1992) dan bakteriosin (Jannah et al., 2014). Lactobacillus casei dapat memecah limbah di dalam tubuh sehingga dapat membantu penyerapan berbagai vitamin dan mineral. Bakteri ini dapat ditemukan pada saluran kemih dan kelamin. Bakteri ini bermanfaat dalam sistem pencernaan (Yanuar, 2015). L. casei bersifat homofermentatif dengan laktat murni yang terbentuk hampir 85\%. Habitatnya pada organ pencernaan (usus) (Jannah et al., 2014).

Bakteri Lactobacillus paracasei ini adalah Isolat bersifat gram positif, Bersifat non motil, Fakultatif anaerob, Heterofermentatif (Sunaryanto 2014). Bakteri Lactobacillus paracasei mempunyai peran meningkatkan daya tahan tubuh, anti peradangan dan menjaga pencernaan lebih baik karena punya kemampuan dalam meningkatkan jumlah bakteri baik dalam usus yaitu Bifidobacteria dan Lactobacilli dan mengurangi keaktifan bakteri berbahaya (sumber penyakit) (Suryani et al., 2017 dan Sunaryanto 2014 ).

Lactobacillus reuteri Bermanfaat dalam sistem kekebalan tubuh dan dapat membantu memperkuat dinding usus dengan mengurangi penyebaran mikroba penyebab peradangan Lactobacillus fermentum memiliki ketahanan alami terhadap antibiotik dan kemoterapi tertentu. Bakteri 
Jurnal Jeumpa, 8 (2) Juli-Desembaer 2021

ini dianggap sebagai vektor potensial dari gen resistensi antibiotik dari lingkungan ke manusia atau hewan ke manusia (Gan et al., 2002). Adapun L.bulgaricus berpotensi sebagai antikolesterol karena diduga mengandung EPS (eksopolisakarida) yang diproduksinya (Teguh, 2008). Selain itu bakteri ini juga berperan dalam pembentukan yoghurt. L.bulgaricus telah digunakan sebagai starter culture untuk fermentasi produk susu (Setiarto, 2018). Lactobacillus fermentum dan Lactobacillus acidophillus merupakan BAL paling sering diteliti. Lu, (2005) menyatakan jumlah Lactobacillus mencapai $70 \%$ dari populasi bakteri yang terdapat pada saluran digestoria.

\section{Lactobacillus crispatus Bakteri}

berbentuk batang. Yang merupakan spesies biota mikro menguntungkan yang menghasilkan hidrogen peroksida yang terletak di vagina, melalui keputihan dan saluran pencernaan vertebrata. Lactobacillus Salivarius adalah spesies bakteri probiotik yang telah ditemukan hidup disaluran digestoria dengan sifat terapteutik yaitu mampu menekan bakteri patogen tumbuh. Lactobacillus brevis berperan dalam proses pembuatan asinan buah buahan dan sayuran. Bakteri ini berbentuk batang yang heterofermentatif. Merupakan spesies asam laktat yang bersifat gram positif dan mampu menghasilkan $\mathrm{CO} 2$ dan asam laktat selama proses fermentasi. Lactobacillus helveticus Bakteri yang dapat menghasilkan asam laktat yang berbentuk batang. Bakteri baik yang hidup didalam sistem pencernaan manusia. Tujuannya untuk menjaga keseimbangan bakteri baik didalam sistem pencernaan. Selain itu, bakteri digunakan dalam pembuatan produk keju. Lactobacillus crispatus Bakteri berbentuk batang. Yang merupakan spesies biota mikro menguntungkan yang menghasilkan hidrogen peroksida yang terletak di vagina, melalui keputihan dan saluran pencernaan vertebrata

Lactobacillus bulgaricus dan Lactobacillus Salivarius merupakan bakteri probiotik yang ditemukan pada usus manusia. L.bulgaricus dapat digunakan untuk membuat minuman probiotik dari sari pepaya (Primurdia dan Kusnadi, 2014). Adapun L.brevis menurut Wikandari et al., (2012) telah digunakan pada pembuatan asinan buah buahan dan sayuran. Bakteri asam laktat merupakan bakteri proteolitik (mampu mencerna protein) dengan menghasilkan enzim proteolitik.

Hasil identifikasi penelitian ini menunjukkan bahwa banyak ditemukannya bakteri asam laktat dari genus Latobacillus 
yag memiliki banyak peran yang menguntungkan untuk manusia dikehidupan sehari hari.

\section{KESIMPULAN}

Berdasarkan literatur review yang dilakukan pada penelitian ini BAL jenis Lactobacillus telah digunakan sebagai probiotik dengan jumlah spesies potensial untuk probiotik sebanyak 56 dari 106 spesies. Banyak manfaat yang dihasilkan dari fermentasi bakteri Lactobacillus, salah satunya adalah pemanfaatan di bidang pangan baik berupa produk makanan, pengawet makanan dll. Hasil dari produk fermentasi bakteri Lactobacillus banyak bermanfaat untuk kesehatan.

\section{DAFTAR PUSTAKA}

Adams, M.R and M.O. Moss. 2008. Food Microbiology. 3rd ed. The Royal Society of Chemistry Publishing, UK.

Afrizal, M. 1989. Study Tingkat Penambahan Starter dan Lama Inkubasi terhadap Mutu Yoghurt. Tesis Teknologi Hasil Pertanian. Fakultas Pertanian. Universitas Lampung. Bandar Lampung

Aulya W, Fadhliani, Mardina V. 2020. Analysis of coliform and colifecal total pollution test on various types of drinking water using the MPN (Most Probable Number) method. Serambi Journal of Agricultural Technology (SJAT), Vol. 2 No. $2: 64-72$.
Badel S, Bernardi T, Michaud P. New perspectives for Lactobacilli exopolysaccharides. Biotechnol Adv. 2011;29(1):54-66.

Claesson, M.J., van Denyer, D. dan O'Toole, P.W. (2007). The genus Lactobacillus - a genomic basis for understandingits diversity. Federation of European Microbiologycal Society Microbiology Letters 269(1): 22-28.

Cunningham, F.E and N.A. Cox. 1987. The Microbilology of Poultry Meat Products. Academic Press Inc, San Diego, California.

Daeschel, M.A. (1989) Antimicrobial subtances from lactic acid bacteria for use as food preservatives. Food Technology 43(1): 164-167.

Fahmida, dan Manin. Potensi Lactobacillus, Acidophilus dan Lactobacillus Fermentum dari Saluran Pencernaan Ayam Buras Asal Lahan Gambut Sebagai Sumber Probiotik Jurnal Ilmiah Ilmu-Ilmu Peternakan Februari, 2010, Vol. XIII, No. 5221.

Fardiaz, S. 1992. Mikrobiologi Pangan I. Jakarta : Bumi Aksara

Farinde, E.O., V.A. Oba Tom, M.A. Oyarekhua, and O.T. Olanipekun. 2010. Physical and Microbial Properties of Fruit Flavored Fermented Cow Milk and Soymilk (Yoghurt-Like) Under Different Temperature of Storage. African J. Food Sci. and Technol. I(5):120-127.

Gan, B.S., Kim, J., Reid, G., Cadieux, P. dan Howard, J.C. (2002). Lactobacillus fermentum RC-14 inhibits Staphylococcus aureus infection of surgical implants in rat. The Journal of Infectious Diseases 185: 1369- 1372. 
Gibson, G.R. and M. Roberfroid. 2000. Handbook Ingredients of Probiotics. CRC Press, Australia.

Haddadin, M.S.Y., S.M. Abdulrahim, E.A. R. Hashlamoun and R.K Robinson. 1996. The effect of Lactobacillus acidophilus on the production and chemical compositon on hen's eggs. Poultry Science. 75:491-494.

Holt J G, Krieg N R, Sneath P H, Stanley J T, \& Williams S.T. 1994. Bergey's Manual of Determinative Bacteriology. Ninth Edition. Williams and Wilkins : New York.

Jannah, A.M., Legowo, A.M., Pramono, Y.B., Al-Baarri, A.N., Abduh, S.B.M., 2014. Total bakteri asam laktat, $\mathrm{pH}$, keasaman , citarasa dan kesukaan yogurt drink dengan penambahan ekstrak buah belimbing. Jurnal Aplikasi Teknologi Pangan 3, 7-11.

Khusaini, M., 2014. Pemanfaatan buah pepaya (Carica pepaya L.) dalam pembuatan yoghurt fruit dengan perbedaan jumlah konsentrasi starter dan lama fermentasi. Jurnal Agrina 1, 23-30.

Krishna, K.L., Paridhavi, M., Patel, J.A., 2008. Review on nutritional, medicinal and pharmacological properties of papaya (Carica papaya Linn.). Natural Product Radiance 7, 364-373.

Levinna Agustine, Yenni Okfrianti, Jumiyati. 2018. Identifikasi Total Bakteri Asam Laktat (Bal) Pada Yoghurt Dengan Variasi Sukrosa Dan Susu Skim. Jurnal Dunia Gizi, Vol. 1, No. 2, Desember 2018: 79-83.

Lu, J., Idris, U. Harmon, B. Hofacre, C. Maurer, JJ, Lee, MD. 2003. Diversity and succesion of the intestinal bacterial community of the maturing broiler chicken. Applied and envron. Microb, 69 : 6816-6824.

Makhfirah N, Fatimatuzzahra C, Mardina V, Hakim R.F. 2020. Pemanfaatan bahan alami sebagai upaya penghambat Candida albicans pada rongga mulut. Jurnal Jeumpa, 7 (2): 400 - 413.

Manin. F., Ella Hendalia, Yusrizal dan Nurhayati. 2006. Effect of Kerinci Duck's Intestinal Probiotic (Bacillus circulans and Bacillus sp) as Feed Addtive on Broiler Performans. Proceedings of The 4th ISTAP “ Animal Production and Sustanable Agriculture in The Tropics" Faculty of Animal Sience, Gajah mada Uniersity, November 8-9, 2006. p : $276-286$.

Nuraida L., Hana, Hartanti A, W and Prangdamurti, E. 2012. Evaluasi potensi lactobacillus yang diisolasi dari air susu ibu untuk mencegah diare karea infeksi E coli K, 1. 1. J. Teknol. Ind pangan. $23: 158-165$.

Otieno, D.O. 2011. Biology of Prokaryotic Probiotics, In Probiotics, Microbiology Monographs (M.T. Liong, ed.) pp. 1- 25.Springer-Verlag. Berlin.

Rusli, Fitri Amalia, Zaraswati Dwyana. 2018. Potensi Bakteri Lactobacillus Acidophilus Sebagai Antidiare Dan Imunomodulator Bioma : Jurnal Biologi Makassar, 3(2): 25-30.

Setiarto. R. Haryo Bimo, Nunuk Widhyastuti, Nandani Dwi Octavia, dan Herson Cahaya Himawan. Produksi sari pepaya (Carica papaya) fermentasi sebagai minuman probiotik antihiperkolesterolemia Jurnal Litbang Industri - Vol. 8 No. 1, Juni $2018: 23$ -30 . 
Sulistiani. 2017. Senyawa Antibakteri yang Diproduksi oleh Lactobacillus plantarum dan Aplikasinya untuk Pengawetan Bahan Ikan. Jurnal Biologi Indonesia 13(2): 233-240

Suryananto, R, Martius, E, MArwoto, B. Uji Kemampuan Lactobacillus Casei Sebagai Agensia Probiotik. Jurnal Bioteknologi dan Biosains, 01(01), pp.9-15.

Suryani, Dedi Nofiandi, Husni Mukhtar, Melona Siska, Abdi Dharma, Nasril Nasir. 2017. Identifikasi Molekular Bakteri Asam Laktat Lactobacillus Paracasei Yang Ada Pada Lapisan Minyak. Jurnal Katalisator. Vol 2 No. 2. E-ISSN : 2502-0943

Teguh, S., 2008. Kandungan beta karoten, polifenol total dan aktivitas "merantas" radikal bebas kefir susu kacang hijau (Vigna radiata) oleh pengaruh jumlah starter (Lactobacillus bulgaricus dan Candida kefir) dan konsentrasi glukosa [Tesis]. Universitas Diponegoro, Semarang.Usman. N. A., K. Suradi , dan J. Gumilar Pengaruh Konsentrasi Bakteri Asam Laktat Lactobacillus Plantarum Dan Lactobacillus Casei Terhadap Mutu Mikrobiologi Dan Kimia Mayones Probiotik. Jurnal Ilmu Ternak, Desember 2018, 18(2):79-85

Usmiati, S., Miskiyah dan Rarah, R.A.M. (2009).The effect of bacteriosin of Lactobacillus sp. SCG 1223 to the microbiological quality of fresh beef. Jurnal Ilmu Ternak dan Veteriner 14(2): 150-166.

Wardinal, Safika dan Yulia Sari Ismail. 2019. Identifikasi Lactobacillus Sp Pada Orangutan Sumatera (Pongo Abelii) Liar Menggunakan Kit Api 50 Chl Di Stasiun Penelitian Suaq
Belimbing Aceh Selatan. Jurnal Biotik, ISSN: 2337-9812, Vol. 7, No. 1, Ed. April, Hal. 49-56

Wikandari, P.R., Suparmo, Marsono, Y dan Rahayu, E.S., 2012. Karakterisasi bakteri asam laktat proteolitik pada bekasam. J. Natur Indonesia 14(2): 120- 125

Yanuar SE, Sutrisno A. Minuman Probiotik dari Air Kelapa Muda dengan Starter Bakteri Asam Laktat Lactobacillus casei. J Pangan dan Agroindustri. 2015;3(3):909-17. 